\title{
Perbandingan Kadar Flavonoid Total Seduhan Daun Benalu Cengkeh (Dendrophthoe Petandra L.) pada Bahan Segar dan Kering
}

\section{Comparison of Total Flavonoid Contents of Dendrophthoe Petandra Leaves Infusion in Fresh and Dry Materials}

\author{
Susilowati ${ }^{1}$, Iin Nurlinda Sari ${ }^{1}$ \\ Email: susilowati@stikesnas.ac.id \\ ${ }^{1}$ Laboratorium Obat Tradisional, Farmasi, Sekolah Tinggi Ilmu Kesehatan Nasional \\ Riwayat Artikel: Dikirim Juli 2020; Diterima September 2020; Diterbitkan Oktober 2020
}

\begin{abstract}
Abstrak
Benalu Cengkeh (Dendrophthoe petandra L.) adalah tanaman yang hidup menempel pada tanaman cengkeh. Tanaman ini sering dianggap hama oleh masyarakat, padahal tanaman benalu ini dapat dimanfaatkan sebagai tanaman obat karena memiliki kandungan fitokimia meliputi flavonoid, terpenoid, tannin, alkaloid dan saponin. Flavonoid merupakan senyawa penanda yang bertanggung jawab terhadap potensi antioksidan dan antikanker daun benalu cengkeh. Dalam penggunaan tanaman obat, masyarakat biasanya menggunakan teknik penyarian sederhana dengan seduhan. Tujuan dari penelitian ini adalah untuk mengetahui perbandingan kadar flavonoid total pada seduhan daun benalu cengkeh segar dan kering sehingga dapat memberikan informasi kepada masyarakat akan preparasi bahan yang tepat sebelum digunakan. Identifikasi awal flavonoid menggunakan uji alkali dengan pereaksi $\mathrm{NaOH}$, uji asam dengan $\mathrm{H}_{2} \mathrm{SO}_{4}$ dan uji wilstatter. Penentuan kadar flavonoid total dilakukan secara spektrofotometri UV-Vis menggunakan pereaksi $\mathrm{AlCl}_{3}$ dan dinyatakan terhadap kuersetin (Quercetin Equivalent). Hasil penelitian menunjukkan daun benalu cengkeh mengandung flavonoid dengan kadar flavonoid total seduhan daun segar sebesar 8,1977 ppm QE dan seduhan daun kering sebesar 5,4407 ppm QE. Analisa perbandingan kadar dengan One Way Anova menunjukkan flavonoid total seduhan daun benalu cengkeh segar lebih besar secara signifikan dibandingkan daun kering.
\end{abstract}

Kata kunci: Daun Benalu cengkeh, Seduhan, Flavonoid

\begin{abstract}
Dendrophthoe petandra $L$. is a plant that attaches itself to cloves. in society, this plant is often considered a pest, even though this parasite plant can be used as a medicinal plant because it contains phytochemicals including flavonoids, terpenoids, tannins, alkaloids and saponins. Flavonoids are marker compounds that are responsible for the antioxidant and anticancer potential of clove parasite leaves. In the use of medicinal plants, people usually use simple extraction techniques with infusion. The aim of this study was to determine of total flavonoid levels ini leaf infusion of fresh and dry clove parasite leaves so as to provide information to the public on the proper preparation of ingredients before use. Identification of flavonoids using the alkaline test with $\mathrm{NaOH}$, acid test with $\mathrm{H} 2 \mathrm{SO} 4$ and willstater test. Determination of total flavonoid levels was carried out by UV-Vis
\end{abstract}


spectrophotometry using $\mathrm{AlCl} 3$ and expressed as quercetin equivalent. The results showed that clove parasite leaves contained flavonoids with total flavonoid levels of 8,1977 ppm QE of fresh leaf infusion and 5,4407 ppm QE of dry leaf infusion. Comparison analysis of levels with One Way Anova showed that the total flavonoids of fresh clove parasite leaves were significantly greater than the dry leaves.

Keywords: Dendrophthoe petandra, infusion, Flavonoids

\section{Pendahuluan}

Benalu cengkeh merupakan salah satu jenis tumbuhan benalu yang hidup di pohon cengkeh. Benalu bersifat hemiparasit atau setengah parasit karena memiliki zat hijau daun (klorofil) yang digunakan untuk proses asimilasi dan hanya menghisap air dan zat organik dari tanaman inangnya (Chang, et al. 1999). Meskipun sebagai tanaman hemiparasit namun pemanfaatan terhadap tanaman tersebut telah banyak dibuktikan. Berdasarkan penelitian yang dilakukan Fitrilia (2015) menunjukkan aktivitas antioksidan yang kuat dari ekstrak air dan ekstrak etanol daun benalu cengkeh yang diuji melalui metode DPPH free radical scavenging dengan nilai $I C_{50}$ berturut-turut sebesar 11,4 $\mu \mathrm{g} / \mathrm{mL}$ dan $6,8 \mu \mathrm{g} / \mathrm{mL}$. Selain itu, berdasarkan uji toksisitas dengan metode Brine Shrimp Lethality Test (BSLT) yang dilakukan oleh Elsyana, et al, (2016) menunjukkan bahwa ekstrak etanol daun benalu cengkeh memiliki nilai $L D_{50} 1673,72 \mu \mathrm{g} / \mathrm{mL}$.

Flavonoid merupakan senyawa metabolit sekunder yang bertanggungjawab terhadap aktivitas antioksidan, antibakteri dan antikanker daun benalu cengkeh (Ikawati et al. 2008). Berdasarkan penelitian Lekal and Watuguly, (2017) kadar flavonoid total pada ekstrak daun benalu cengkeh sebesar 13,7021\% dan menjadi $0,2819 \%$ pada rebusan teh daun benalu cengkeh. Menurunnya kadar flavonoid dalam daun benalu cengkeh dikarenakan flavonoid yang tidak stabil terhadap suhu yang tidak terkontrol. Merebus merupakan teknik penyarian dengan suhu tinggi sehingga menyebabkan kerusakan dinding dan membran sel tanaman serta dapat menurunkan kandungan flavonoid dari tanaman tersebut (Syaifuddin., 2015). Oleh karena itu, salah satu alternatif metode penggunaan daun benalu cengkeh yang mudah diaplikasikan masyarakat tanpa panas yang berkelanjutan adalah dengan teknik seduhan.

Seduhan merupakan salah satu teknik pengolahan tanaman obat yang secara empirik digunakan oleh masyarakat. Seduhan dapat dilakukan terhadap bahan segar dan kering dari suatu tanaman obat. Penelitian yang dilakukan oleh Putri and Wuryandari, (2018) menunjukkan terdapat perbedaan kandungan flavonoid total dari seduhan daun tin segar dan kering. Adanya perbedaan kadar senyawa utama dalam daun benalu cengkeh tentunya akan berdampak terhadap potensi yang diharapkan dari penggunaan tanaman obat tersebut. Berdasarkan hal tersebut perlu dilakukan analisis kadar flavonoid total dalam seduhan daun benalu cengkeh segar dan kering sehingga dapat memberikan informasi kepada masyarakat terkait jenis bahan yang digunakan untuk memanfaatkan daun benalu cengkeh secara optimal.

\section{Metode Penelitian}

Alat

Alat yang digunakan adalah spektrofotometri UV-Vis ( Shimadzu UV-1280 No. A120654), sepasang kuvet ( Hellma Analytic type No 100. 600 QG Light path lotum), neraca analitik (Ohaus PA214 sensitivitas $0,0001 \mathrm{~g}$ ), nampan, kain flanel, alumunium foil, Panci, kompor listrik S- 300, corong kaca, pipet, baskom, sorbet, tissue, labu ukur, cawan porselin, sendok takar, rak tabung reaksi, pisau, Waterbath 
Bahan

Bahan yang digunakan Daun Benalu cengkeh di daerah Karanganyar, Kuersetin (Sigma Aldrich), kertas saring, $\mathrm{NaOH}$, Aquadest, $\mathrm{HCl}$ pekat, Serbuk Mg, Metanol p.a (Merck), Kalium Asetat (Merck), H2S04, AlC13 (Merck)

Tahapan Penelitian

1. Pembuatan Seduhan Segar

Daun benalu segar dicuci kemudian dikering-anginkan. Selama 4 menit. Setelah itu dipotong kecil-kecil dengan lebar 2-3 cm,kemudian diambil sebanyak 6,25 gram dan diseduh dengan $100 \mathrm{~mL}$ air mendidih, sampel didiamkan sampai dingin selama 7 menit dan kemudian disaring (Putri and Wuryandari 2018).

2. Pembuatan Seduhan Kering

Ambil daun benalu segar yang telah dipotong kecil-kecil berukuran 2-3 cm lalu keringkan dengan oven bersuhu $30 \mathrm{oC}$, setelah kering daun benalu ditimbang sebanyak 6,25 gram, lalu diseduh dengan $100 \mathrm{~mL}$ air mendidih, tunggu hingga dingin selama 7 menit dan kemudian disaring (Putri and Wuryandari 2018)

3. Uji Kualitatif Flavonoid

Uji keberadaan flavonoid dalam sampel mengacu pada Hanani (2015).

a. Uji wilstatter

Sampel ditambahi 2-4 tetes $\mathrm{HCl}$ pekat dan ditambahkan 2-3 potongan kecil Mg. Hasil positif ditandai warna orange, kuning, sampai warna merah.

b. Uji Reagen Alkali

Sampel ditambahkan dengan beberapa tetes larutan $\mathrm{NaOH}$. Hasil positif ditandai warna kuning yang terang.

c. Uji Reagen H2SO4

Sampel ditambahkan dengan beberapa tetes larutan H2SO4. Hasil positif ditandai warna merah tua dan hitam kecoklatan.

4. Uji kuantitatif flavonoid total

Penetapan kadar Flavonoid total yang digunakan dalam penelitian ini mengacu pada metode (Chang et al. 2002). a. Pembuatan larutan standart kuersetin Kuersetin sebesar $25 \mathrm{mg}$ dilarutkan dengan metanol sampai $25 \mathrm{~mL}$ dan didapatkan larutan baku induk (1000 ppm), selanjutnya buat seri kosentrasi sebesar 4ppm, 6ppm, 8ppm, 10 ppm, 12 ppm, kemudian larutan baku induk dipipet dan dimasukan kedalam labu ukur dan diencerkan dengan metanol p.a sampai $5 \mathrm{~mL}$.

b. Penentuan panjang gelombang maksimal Diambil konsentrasi larutan baku 10 ppm dan dimasukkan ke dalam labu ukur 10,0 ml kemudian tambahkan $3 \mathrm{ml}$ metanol, 0,2 $\mathrm{ml}$ $\mathrm{AlCl} 3$ 10\%, 0,2 $\mathrm{ml} \mathrm{CH} 3 \mathrm{COOK} 1 \mathrm{M}$ dan aquadest sampai tanda batas kemudian dikocok sampai homogen. Lakukan scanning pada panjang gelombang 400-500 nm. Kemudian amati kurva hubungan antara panjang gelombang dengan absorbansi dan tentukan panjang gelombang maksimalnya dari spektrogram yang diperoleh

c. Penentuan operating time

Diambil konsentrasi larutan baku 10 ppm dan dimasukkan ke dalam labu ukur 10,0 ml kemudian tambahkan $3 \mathrm{ml}$ metanol, 0,2 ml $\mathrm{AlCl} 3$ 10\%, 0,2 ml CH3COOK $1 \mathrm{M}$ dan aquadest sampai tanda batas kemudian dikocok sampai homogen. Panjang gelombang kuersetin diukur dari menit ke 0 40. Kemudian diamati hubungan antara absorbansi dan waktu hingga dapat ditentukan operating timenya.

d. Pengukuran flavonoid total

Sampel uji dan larutan standar masingmasing diambil 0,5 $\mathrm{mL}$ lalu ditambahkan 3 $\mathrm{mL}$ metanol p.a, 0,2 AlCl3 $10 \%, 0,2 \mathrm{~mL}$ kalium asetat dan di tambahkan aquadest sampai $10 \mathrm{~mL}$ setelah itu diinkubasi selama 30 menit dan diukur absorbansinya dengan Spektrofotometri UV-Vis pada panjang gelombang 439,5 nm. Pengukuran ini dilakukan secara triplo. Selain itu sebelum pengukuran dilakukan optimasi untuk mencari operating time dan panjang gelombang maksimal. 


\section{Analisis Data}

1. Penentuan kadar flavonoid total

Kadar flavonoid dihitung dengan menggunakan persamaan dari kurva regresi linier kuersetin. Data absorbasi yang diperoleh dari penetapan kadar flavonoid dimasukkan ke dalam persamaan kurva kalibrasi sebagai y, dengan demikian akan diperoleh nilai $\mathrm{x}$ sebagai konsentrasi flavonoid dalam larutan sampel kerja. Hasil dinyatakan dengan kesetaraan larutan standar flavonoid menggunakan baku pembanding kuersetin sehingga dinyatakan sebagai Quercetine Equivalent (QE). Persamaan regresi linear dapat dilihat pada rumus 1.

$$
y=b x+a \ldots \ldots \ldots . .(\text { rumus } 1)
$$

2. Analisis perbandingan

Flavonoid total dari seduhan daun segar dan kering benalu cengkeh dilakukan dengan software SPSS yaitu uji One Way Anova. Kadar flavonoid dimasukkan sebagai variabel dependent dan air seduhan dimasukkan sebagai variabel faktor. Sebelum dilakukan uji tersebut maka perlu dilakukan Normality test dan Homogeneity test of Variances untuk mengetahui normalitas dan homogenitas dari data yang diuji. Apabila hasil uji kenormalan $<0,05$ maka data berdistribusi normal dan dapat disimpulkan jika $>0,05$ maka tidak ada perbedaan yang nyata antara seduhan kering dan segar.

\section{Hasil dan Pembahasan}

Sampel yang digunakan pada penelitian ini adalah daun benalu cengkeh Dendropthoe pentandra (L.) Miq. Yang diambil di Desa Mereng, Kelurahan Tlobo, Kecamatan Jatiyoso, Kabupaten Karanganyar. Daun yang diambil adalah daun yang berwarna hijau agak tua karena pada daun tua sangat berpengaruh nyata terhadap kadar total flavonoid yang merupakan senyawa bioaktif yang berperan sebagai antioksidan. Proses pengambilan daun dilakukan pada pagi hari dengan tujuan untuk mendapatkan senyawa aktif yang tinggi, karena jika dipetik pada saat siang hari tanaman akan mengalami fotosistensis sehingga senyawa aktif yang akan ditarik kurang optimal (Yulian and Safrijal 2018).

Pada persiapan bahan, daun disortasi terlebih dahulu Daun benalu yang telah dipetik disortasi basah kemudian dicuci dengan air mengalir untuk menghilangkan kotoran yang menempel pada daun. Selanjutnya bahan dirajang dengan ukuran 2-3 cm yang bertujuan untuk mempercepat proses pengeringan. Selain itu, peranjangan juga dapat mempengaruhi kadar flavonoid total yang dihasilkan karena semakin kecil ukuran daun maka semakin luas permukaanya sehingga kadar yang didapatkan akan lebih optimal. Hal ini sejalan dengan penelitian yang dilakukan oleh Tambun et al., (2016) bahwa ukuran daun dapat mempengaruhi kadar flavonoid yang dihasilkan. Pada persiapan daun kering, daun dikeringkan dengan oven bersuhu $30^{\circ} \mathrm{C}$, pengeringan pada suhu $30^{\circ} \mathrm{C}$ agar senyawa-senyawa metabolit sekunder yang terdapat pada daun tidak rusak hal pengeringan ini juga yang bertujuan untuk menghilangkan kadar air dalam sampel agar terhindar dari perkembangbiakan mikroba, tahan terhadap penyimpanan dalam jangka waktu yang lama. Pengeringan dilakukan selama 3 hari, setelah proses pengeringan dilakukan sortasi kering.

Sampel uji daun benalu yang telah disiapkan dilakukan penyeduhan dengan 100 $\mathrm{mL}$ aquadest yang telah dipanaskan dan penyeduhan dilakukan selama 7 menit. Volume seduhan yang diperoleh dari hasil penyeduhan daun segar sebesar $95 \mathrm{~mL}$ dengan organoleptis larutan jernih berwarna kuning cerah, sedangkan pada daun kering diperoleh volume sebesar $83 \mathrm{~mL}$ dengan organoleptis larutan berwarna kuning pekat. 
Tabel I. Uji Kualitatif seduhan segar dan kering

\begin{tabular}{ccc}
\hline Uji Flavonoid & Seduhan daun segar & Seduhan daun kering \\
\hline Uji Alkali & + & + \\
Uji dengan $\mathbf{H}_{2} \mathrm{SO}_{4}$ pekat & + & + \\
Uji wilstater Cyanidin & + & + \\
\hline
\end{tabular}

Berdasarkan tabel I menunjukkan secara kualitatif seduhan daun segar dan kering positif mengandung Flavonoid. Pada uji alkali sampel seduhan ditambahkan $\mathrm{NaOH}$ menghasilkan warna kuning lebih intens (Gambar 1). Hal ini

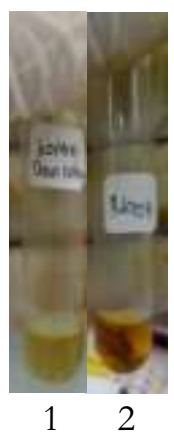

(A) disebabkan adanya penguraian oleh basa menjadi molekul asetafenon yang berwarna kuning karena adanya pemutusan ikatan pada struktur isoprene (Kusnadi and Devi 2017)

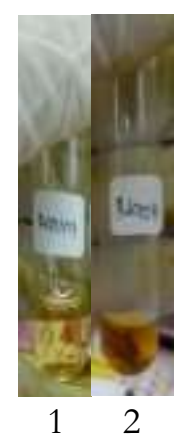

(B)

Gambar 1. Hasil uji flavonoid dengan alkali, A. Seduhan daun benalu segar, B.

Seduhan daun benalu kering (1) Sampel Uji (2) Hasil Uji Dengan $\mathrm{NaOH}$

Pada identifikasi flavonoid kedua dengan $\mathrm{H}_{2} \mathrm{SO}_{4}$ pekat menunjukan pembentukan warna seduhan menjadi coklat kehitaman (Gambar 2). Hal ini disebabkan karena senyawa flavonoid yang terdapat dalam

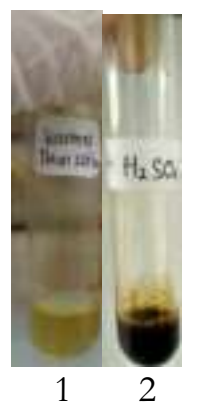

(A) sampel mengalami reaksi oksidasi yang menyebabkan terbentuknya senyawa kompleks, sehingga menghasilkan warna merah tua atau coklat kehitaman (Kusnadi and Devi 2017).

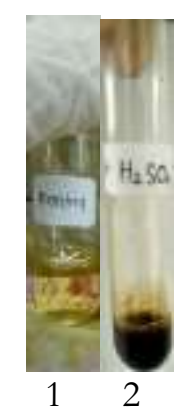

(B)

Gambar 2. Hasil uji flavonoid dengan asam A. Seduhan daun benalu segar, B. Seduhan daun benalu kering (1) Sampel Uji (2) Hasil Uji Dengan $\mathrm{H}_{2} \mathrm{SO}_{4}$ 
Identifikasi Flavonoid ketiga adalah uji Wilstater Cyanidin dengan menggunakan reagen serbuk $\mathrm{Mg}$ dengan $\mathrm{HCl}$ pekat. Pada uji ini jika suatu sampel mengandung flavonoid ditandai dengan berubahnya warna menjadi kuning jingga sampai warna merah. Pada uji ini dilakukan penambahan $\mathrm{HCl}$ dimaksudkan untuk mendeteksi senyawa flavanoid untuk menghidrolisis flavonoid menjadi aglikonya,

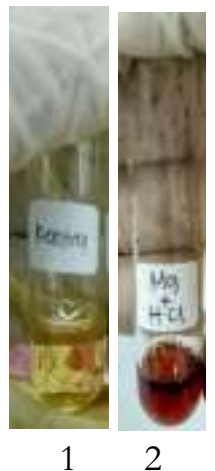

(A)

yaitu dengan menghidolisis O-glikosil menjadi aglikon (tidak terikat gula) sehingga $\mathrm{H}^{+}$dilepas dan $\mathrm{O}$ terikat oleh $\mathrm{Mg}$ sehingga flavanoid yang telah tereduksi dengan serbuk $\mathrm{Mg}$ dan $\mathrm{HCl}$ memberikan warna merah, kuning, atau jingga (Baud et al. 2014). Hasil perubahan warna tersebut dapat dilihat pada gambar 3 yang menunjukan perubahan warna seduhan menjadi merah.

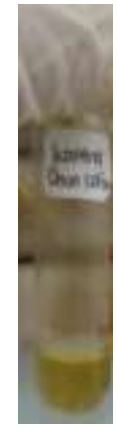

1

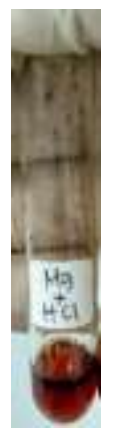

2

Gambar 3. Hasil uji wilstater, A. Seduhan daun benalu segar, B.

Seduhan daun benalu kering (1) Sampel Uji (2) Hasil Uji dengan Wilstater Cyanidin

Penetapan kadar flavonoid yang terdapat pada daun benalu cengkeh dilakukan dengan metode spektrofotometri UV-Visible karena flavonoid memiliki gugus kromofor dan ausokrom. Pada penelitian ini menggunakan metode alumunium klorida dengan prinsip terjadinya pembentukan kompleks stabil antara alumunium klorida dengan gugus keto pada atom C-4 dan gugus hidroksi pada atom C-3 atau C-5 golongan flavon dan flavonol. Selain itu, pembentukan komplek labil pada orto hidroksi di cincin B. Standar kuersetin yang digunakan merupakan flavonoid golongan flavonol yang memiliki gugus keto pada atom C-4 dan juga gugus hidroksil pada atom C-3 dan C-5 yang bertetangga serta memiliki orto hidroksi pada cincin B sehingga reaksi komplek antara kuersetin dan $\mathrm{AlCl} 3$ dapat terbentuk seperti yang ditunjukkan pada Gambar 4 (Markham, 1988). Pembentukan kompleks kuersetin alumunium klorida ditunjukkan dengan larutan berwarna kuning sehingga terjadi pergeseran panjang gelombang kearah visible (sinar nampak) dan penambahan kalium asetat berfungsi untuk menstabilkan senyawa kompleks yang terbentuk (Chang et al. 2002).

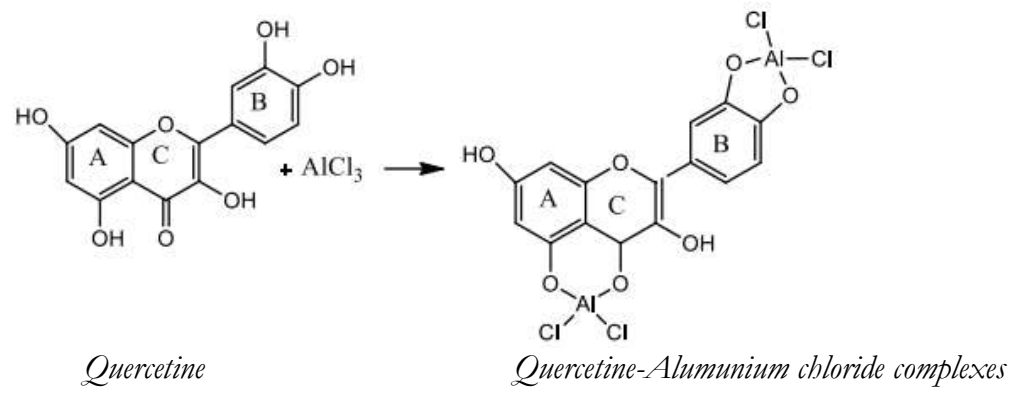

Gambar 5. Pembentukan senyawa kompleks kuersetin-alumunium klorida 
Penentuan panjang gelombang yang digunakan untuk analisis kuantitatif adalah panjang gelombang yang memiliki absorbansi maksimal sehingga menunjukkan kepekaan yang maksimal. Berdasarkan hasil penentuan panjang gelombang maksimal kuersetin diperoleh hasil panjang gelombang 439,5 nm.
Selanjutnya dilakukan pengukuran Operating Time yang merupakan waktu agar senyawa flavonoid bereaksi dengan $\mathrm{AlCl}_{3}$ secara optimal. Berdasarkan hasil pengukuran yang dilakukan tiap menit selama 60 menit menunjukkan operating time komplek kuersetin pada menit ke-30.

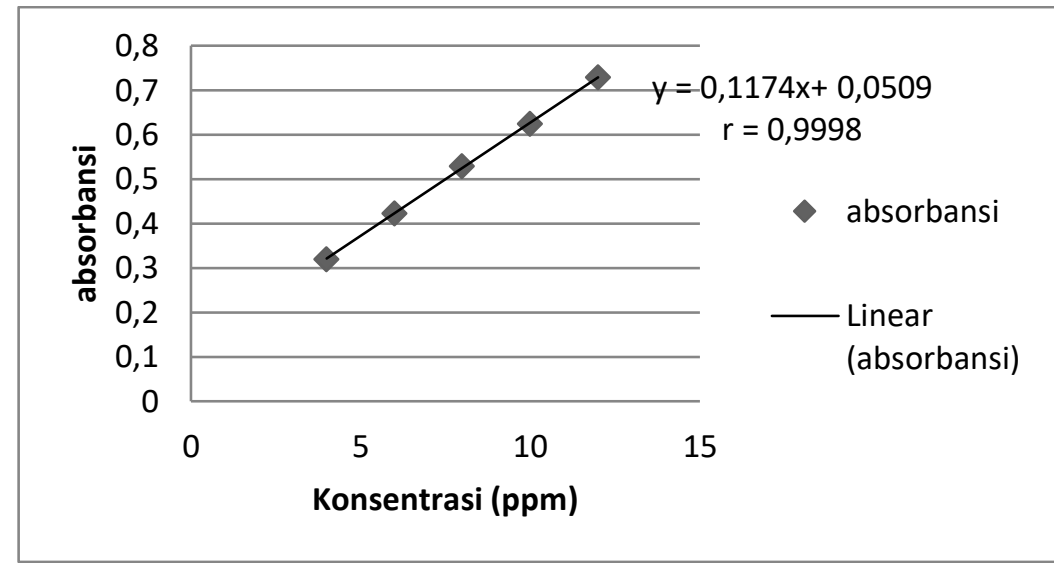

Gambar 5. Kurva Regresi Linear Kuersetin dengan Rumus Regresi linier $y=0,1174 x+0,0509$ dan nilai $r=0,9998$

Seri konsentrasi kurva baku dibuat dengan konsentrasi 4 ppm, 6 ppm, 8 ppm, 10 ppm, dan 12 ppm. Apabila seri kurva baku memenuhi hukum lambert-beer, maka absorbansi akan berbanding lurus dengan konsentrasi. Hal ini ditunjukkan dengan kurva baku yang berbentuk garis lurus dengan $r$ mendekati angka 1 yang berarti hubungan antara kurva baku dan absorbansi adalah linear. Kurva regresi linier baku kuersetin dapat dilihat pada gambar 5 .

Tabel II. Kadar Flavonoid total seduhan daun benalu cengkeh

\begin{tabular}{lccccc}
\hline $\begin{array}{c}\text { Sampel } \\
\text { uji }\end{array}$ & Triplo & Abs & $\begin{array}{c}\text { Kadar Terukur } \\
\text { (ppm QE) }\end{array}$ & $\begin{array}{c}\text { Rata-rata } \\
\text { (ppm QE) }\end{array}$ & $\%$ \%V \\
\hline Seduhan & 1 & 0,532 & 8,1453 & & \\
daun & 2 & 0,535 & 8,1846 & 8,1977 & $0,7321 \%$ \\
segar & 3 & 0,538 & 8,2632 & & \\
Seduhan & 1 & 0,390 & 5,3555 & & \\
daun & 2 & 0,395 & 5,4538 & 5,44073 & $1,4593 \%$ \\
segar & 3 & 0,398 & 5,5127 & & \\
\hline
\end{tabular}

Berdasarkan rumus regresi linier diperoleh kadar flavonoid total seduhan daun segar dan kering masing-masing yang ditunjukkan pada tabel II. Pada Uji kuantitatif seduhan daun benalu didapatkan kadar flavonoid total pada seduhan segar segar dengan rata-rata 8,1977 ppm QE dan kadar flavonoid total benalu kering rata- rata yaitu 5,44073 ppm QE. Berdasarkan analisa parametrik menggunakan analisa One Way Anova, menunjukkan nilai signifikansi kadar flavonoid sebesar $0,000<$ 0,05 . Hal ini menunjukkan terdapat perbedaan yang signifikan antara kadar flavonoid total dari seduhan daun segar dan seduhan daun kering.

Kadar flavonoid total dalam seduhan daun segar lebih tinggi dibandingkan kadar flavonoid dalam seduhan daun kering. Penelitian ini sejalan dengan penelitian Putri and Wuryandari, (2018) yang menunjukkan kadar flavonoid total seduhan daun tin segar lebih tinggi dibandingkan dengan daun kering dengan kadar berturut-turut sebesar $0,0105 \pm 0,0003 \%$ dan 0,0025 $\pm 0,0002 \%$. Hal ini dipengaruhi oleh beberapa faktor yang salah satunya dikarenakan senyawa flavonoid mudah teroksidasi pada suhu tinggi. Adanya pemberian 
panas pada proses pengeringan menunjukkan dapat menurunkan kadar senyawa flavonoid dalam daun benalu cengkeh. Hal ini dibuktikan pada daun benalu yang telah dikeringkan selama 3 hari selama 45 jam pada suhu 30 menit, memiliki kadar yang lebih kecil dari daun benalu segar. Menurut penelitian Saragih (2014), semakin lama waktu pengeringan maka kadar senyawa yang terkandung semakin menurun. Hal ini disebabkan oleh sifat senyawa flavonoid yang tidak tahan terhadap panas.

\section{Simpulan}

Seduhan daun benalu cengkeh segar memiliki kandungan flavonoid total lebih tinggi secara signifikan dibandingkan daun kering dengan kadar masing-masing secara berurutan sebesar 8,1977 ppm $\pm 0,7321 \%$ dan $5,44073 \mathrm{ppm} \pm 1,4593 \%$.

\section{Ucapan Terimakasih}

Ucapan terimakasih diberikan kepada Lembaga Penelitian dan Pengabdian Kepada Masyarakat dan Laboratorium Obat Tradisional Sekolah Tinggi Ilmu Kesehatan Nasional dalam memfasilitasi dilaksanakanya penelitian ini.

\section{Daftar Pustaka}

Baud, Grace S, Meiske S Sangi, and Harry S J Koleangan. 2014. "Analisis Senyawa Metabolit Sekunder dan Uji Toksisitas Ekstrak Etanol Batang Tanaman Patah Tulang ( Euphorbia Tirucalli L .) dengan Metode Brine Shrimp Lethality Test Analysis Secondary Metabolit Compoun and Toxicity Test of Stem Plant Etha." Jurnal Ilmiah Sains 14 (2): 1-8.

Chang G.W., Wahyuningsih M. S. H.and Yustina A. A. A., 1999, "Effect of Benalu (Dendrophtoe sp.) Leaves Extract on the Male Rat (Rattus Norvegicus) Benzidine Induced Hepatotoxicity," Journal Kedokteran Yarsi, Vol. 7, 1, pp. 121-132.

Chang, Chia Chi, Ming Hua Yang, Hwei Mei Wen, and Jiing Chuan Chern. 2002. "Estimation of Total Flavonoid Content in Propolis by Two Complementary Colometric Methods." Journal of Food and Drug Analysis 10 (3): 178-82.

Elsyana, Vida, Maria Bintang, and Bambang Pontjo Priosoeryanto. 2016. "Cytotoxicity and Antiproliferative
Activity Assay of Clove Mistletoe (Dendrophthoe Pentandra (L.) Miq.) Leaves Extracts." Advances in Pharmacological Sciences 2016.

Fitrilia, Tiana. 2015. "Ekstrak Daun Benalu Cengkeh (Dendrophthoe Pentandra (L.) Miq) Sebagai Agen Antioksidan Dan Antidiabetes Secara In Vitro." Sekolah Pascasarjana IPB.

Ikawati, Muthi, Andy Eko Wibowo, Navista Sri, U Octa, and Rosa Adelina. 2008. "Pemanfaatan Benalu Sebagai Agen Antikanker." Fakultas Farmasi Universitas Gadjah Mada, no. May 2008: 1-9.

Kusnadi, Kusnadi, and Egie Triana Devi. 2017. "Pancasakti Science Education Journal." Pancasakti Science Education Journal 2 (9): 56-67.

Lekal, Jecklyn A, and Th Watuguly. 2017. "Analisis Kandungan Flavonoid Pada Teh Benalu (Dendropohtoe Pentandra ( L .) Miq .)." Biopendix 3 (2): 154-58.

Markham, K.R., 1988, Cara Mengidentifikasi Flavonoid, diterjemahkan oleh Kosasih Padmawinata, 15, Penerbit ITB, Bandung.

Putri, Oktavina Kartika, and Wahyu Wuryandari. 2018. "Efek Suhu Penyeduhan Daun Tin (Ficus Carica) Segar Dan Kering Terhadap Kadar Fenolik Total." Jurnal Teknologi Pangan 12 (2): 1-6.

Saragih, Reskita. 2014. "Uji Kesukaan Panelis Pada Teh Daun Torbangun (Coleus amboinicus)".Jurnal Kesehatan dan Lingkungan.1(1): 46-52

Syaifuddin, 2015, "Uji Aktivitas Antioksidan Bayam Merah (alternanthera amoena voss.) Segar dan Rebus Dengan Metode DPPH (1,1 -diphenyl-2- picylhydrazyl)", Skripsi, Pendidikan Biologi Fakultas Ilmu Tarbiyah Dan Keguruan Universitas Islam Negeri Walisongo, Semarang,

Tambun, Rondang, Limbong Harry P, Christika Pinem, and Manurung Ester. 2016. "Fenol Dari Lengkuas Merah Influence Of Particle Size, Time And Temperature To Extract Phenol." Jurnal Teknik Kimia USU 5 (4): 53-56.

Yulian, Muammar, and Safrijal. 2018. "Uji Aktivitas Antioksidan Daun Benalu Kopi (Loranthus Ferrugineus Roxb.) Dengan Metode DPPH (1,1 - Difenil -2Pikrilhidrazil)." Lantanida Journal 6 (2). 